\title{
COLORADOSCHOOLOFMINES
}

EARTH•ENERGY•ENVIRONMENT

DiVISION OF ECONOMICS AND BUSINESS

WORKING PAPER SERIES

\section{Economic Incentives and Conservation: Crowding-in Social Norms in a Groundwater Commons}

Steven M. Smith

\author{
Working Paper 2017-08 \\ http://econbus-papers.mines.edu/working-papers/wp201708.pdf \\ Colorado School of Mines \\ Division of Economics and Business \\ 1500 Illinois Street \\ Golden, CO 80401
}

July 2017 
Colorado School of Mines

Division of Economics and Business

Working Paper No. 2017-08

July 2017

Title:

Economic Incentives and Conservation: Crowding-in Social Norms in a Groundwater Commons*

Author(s):

Steven M. Smith

Division of Economics and Business

Colorado School of Mines

Golden, CO 80401

ssmith1@mines. edu

\begin{abstract}
Price-based interventions can be corrective where users extract from a common resource, but may also impact existing social norms, often crowding them out. In contrast, I find a pumping tax implemented by a group of irrigators in Southern Colorado effectively crowded-in pro-conservation norms, enhancing the financial incentive's impact. Using a unique, spatially oriented panel-data set of groundwater wells, I separate the direct role of increased pumping costs from the indirect effect transmitted through altered conservation norms. To quantify conservation, I estimate how pumping at one well responds to pumping at nearby wells, instrumenting with pumping permits, and interact that behavior with a difference-in-difference framework. The fee directly accounts for approximately $61 \%$ of the reduced pumping and the remaining 39\% comes from crowding-in conservation norms. I hypothesize the internal process provided a signal of group commitment and the knowledge that others are paying a fee lead to more unconditional conservers.
\end{abstract}

$J E L$ classifications: Q15, Q25, H23

Keywords: Irrigation, Groundwater, Climate Change, Conservation, Social Norms

* Smith is corresponding author. Smith acknowledges financial support from National Science Foundation, Grant BCS-1115009. 


\section{Introduction}

The "tragedy of the commons" describes the logic that the divergence between private and social incentives inherent in common-pool resources (CPRs) lead to their inevitable over-use (Hardin 1968). The lack of conservation arises from the incomplete economic property rights, resulting in some of the benefits or costs accruing to an agent other than the decision maker. ${ }^{1}$ Despite the incomplete private property rights, many groups have curtailed over-use of resources through local rules and norms (Ostrom 1990). Rather than being guided solely by financial considerations, users are driven by social preferences, reciprocity, and moral concerns as well.

Still, economists often advocate for the use of economic incentives to provide additional incentive to behave in a more efficient fashion (Pigou 1920). From an efficiency standpoint economic based tools - taxes, subsidies, or tradable permits - are favored over less flexible environmental regulations (Goulder \& Parry 2008). Accordingly, the use of economic based tools are often considered and increasingly implemented, and due to political reasons, more often in the form of tradable permits or subsidies. Europe, for example, turned to a carbon market to address the emissions contributing to global warming (Capoor \& Ambrosi 2008), while other instances on smaller scale, like a groundwater commons in Nebraska, have also implemented tradable permits (Brozović \& Young 2014). More generally, there has been a movement to adopt payment for environmental services (PES) to reward and induce conservation by introducing financial incentives (Engel et al. 2008; Wunder et al. 2008).

\footnotetext{
${ }^{1}$ Because of the reciprocal nature of public goods and CPRs, it is unimportant whether I view conservation as provision of a public good or its absence an over-appropriation of the CPR.
} 
Where social norms already provide some conservation, more modest economic tools can be introduced to bring outcomes closer to the social optimum based on the logic that prices and norms are independent from one another. However, since the 1970s many scholars have drawn on psychology to suggest economic incentives interact with other motivations and that economist should bear in mind psychological factors in greater detail (Frey 1994). The implication is that the introduction of economic incentives may crowd-out or crowd-in internal motivation to behave in a pro-social manner. The literature offers a wide range of explanations why the presence of economic incentives would change behavior beyond the alteration of relative prices and why they are not necessarily separable: aversion to control, release from moral obligation, reduced recognition of being "good", and an update in the value of the behavior (Rode et al. 2014; Frey 1994; Bowles 2008; Bolle \& Otto 2010).

In this paper I provide empirical evidence from a natural experiment that the use of economic incentives can crowd-in additional conservation. Specifically, I analyze the case of a groundwater extraction tax applied to irrigators in San Luis Valley (SLV), Colorado. Following the increased cost, irrigators substantially changed their behavior, including reducing groundwater pumping by an average of 30 percent, corresponding to an estimated price elasticity of -0.79 (Smith et al. 2018). Given that the median irrigation water demand price elasticity in the literature is -0.16 (Scheierling et al. 2006) and groundwater taxes elsewhere have failed to yield reductions (Schuerhoff et al. 2013; Yang et al. 2003), the reduction in SLV is notably large. Therefore it becomes important that this tax was not externally imposed, but rather was the outcome of an internal 
process within a region that generally exhibits high levels of collective-action (Cody et al. 2015).

To assess how much of the reduction is attributable directly to the tax versus any indirect effect from crowding-in social norms, I combine a five-year panel of well-level pumping data with geospatial well characteristic data. For conservation based on social norms, I use spatial variation and consider the narrow but identifiable measure of how irrigators respond to pumping by their neighbors. In order to address the simultaneity bias - that neighbors' pumping is a function of your pumping - I rely on the permitted flow to instrument for the neighbors' pumping. Finally, I establish the impact of the tax on this behavior by employing a difference-in-difference framework, taking advantage of the fact that initially only a subset of wells confronted the tax for a number of years. This framework allows me to not only identify the direct effect of the tax, but also whether an indirect effect exists by holding nearby pumping constant and testing whether irrigators pump relatively more or less following the intervention. The results indicate that a majority of the reduction is due directly to the tax, but also that a substantail portion of the reduction stems from pumping relatively less in response to nearby pumping. The possible factors that lead to crowding-in in this situation are considered in more detail.

\section{Background}

\subsection{Crowding}

Titmuss (1970) first brought wide attention to the idea of crowding-out, suggesting the use of payments, rather than relying on free donations, actually reduced the number of people willing to provide blood for medical purposes. In a more convincing empirical design, Gneezy and Rustichini (2000) show that the introduction of fines at a day-care for 
late pickups led to increased tardiness among parents. In general, there is support for an interaction between prices and social norms across a wide variety of activities, usually crowding-out (Deci et al. 1999)

In light of the crowding literature, there is considerable skepticism that prices are always appropriate to induce conservation because social norms towards conservation can be crowded out. For instance, Kerr et al. (2012) find that community members are less willing to attend a communal clean up when offered a small reward than when no financial incentive is mentioned. Rode et al. (2014) provide a review of the environmental-crowding literature. The extant empirical evidence, primarily stemming from lab and field experiments, yields mixed results. In many cases, evidence suggests some crowding-out, though not always statistically significant. More generally, prices may just be representative of externally imposed rules that can undermine group-norms. In experimental settings, development of social norms to foster cooperation and internal adoption of rules often outperform exogenously imposed regulations (Cardenas 2000; Lopez et al. 2012; Vyrastekova \& Soest 2003). The better outcomes may be linked to the communication process inherent in developing local rules rather than the source of the rules per se, suggesting external rules do not inherently have a crowding-effect, especially if participants are permitted to communicate regardless of the source of regulation (Abatayo \& Lynham 2016).

The literature does recognize the possibility that the introduction of prices can crowd-in pro-social behavior (Frey 1994; Bolle \& Otto 2010). In these cases, the price may enhance self-esteem through recognition, provide a normative signal that the behavior is desired, or by reducing pressure to act selfishly by forcing others to participate in pro- 
social behavior. Empirical evidence, however, is considerably lacking within the environmental context. In CPR game field experiments both Narloch et al. (2012) and Rodriguez-Sickert et al. (2008) find prices may crowd-in conservation practices. But the evidence of crowding-in, especially in an actual intervention in the real world, is unavailable. Many point to the small fee on plastic bags that induced a 90 percent reduction in Ireland as an example (Convery et al. 2007; Rosenthal 2008).

\subsection{Economics of Groundwater Extraction}

When extracting water from aquifers, irrigators confront at least two externalities. Though recharge rates vary depending on physical characteristics, generally aquifers resemble non-renewable resources (Koundouri 2004a). Accordingly, there is a user cost to extraction today: the foregone use of the water in the future. When this scarcity rent is ignored irrigators pump myopically based only on today's marginal costs and marginal benefits, extracting relatively too much now. The second externality is of a spatial nature. Property rights to the overlying land do not fully define the property rights to underlying aquifer because of lateral movements of groundwater. Extraction at one well lowers the water table for nearby wells, increasing the marginal costs of extraction at nearby wells. Irrigators can behave strategically, pumping more before the neighbors' pumping lowers their own water level. Collectively, the process lowers the water table beyond the optimal level and imposes additional pumping costs. Notably, the externalities are not independent. Because the groundwater rights are not secure, irrigators have little incentive to consider the user cost, as it is not clear they will be able to capture the conserved water in the future and can instead only compete contemporaneously to lay 
claim to the water. On net, irrigators are expected to forego conservation of groundwater in favor of increased extraction today.

The presence and extent of the divergence between the social optimum extraction path and those induced by the external costs have been the topic of much debate. Gisser and Sanchez (1980), using linear programming, found that the difference between optimal control and competitive pumping were negligible. Variations of the model have yielded similar results (Koundouri 2004b) with welfare gains of optimal management from status quo often falling below 10 percent, though some studies have found the gains are potentially much larger (Brill \& Burness 1994; Koundouri 2000; Worthington et al. 1985). A possible explanation for the small gains more commonly identified is the use of the "bath tub" model in which extraction at one well immediately reduces the water level across the entire aquifer. ${ }^{2}$ The gains from optimal management may be larger if the externality is spatially explicit, meaning that the externality is more local and heterogeneous in nature, creating larger aggregate losses (Brozović et al. 2010; Guilfoos et al. 2013).

Empirically, it also remains unclear whether the irrigators respond in a strategic fashion. In general, empirical evidence based on observed pumping is lacking because pumping is often not measured and recorded. What studies have been conducted yield mixed results. Huang et al. (2013) report evidence of strategic pumping in China while Pfeiffer \& Lin (2012) find evidence, though relatively small in magnitude, of strategic pumping in Kansas, US. Savage \& Brozović (2011), in contrast, find little support for such behavior

\footnotetext{
2 The small gains under this model are because the externality is so diffuse, no one stands to gain much from reducing it.
} 
in Nebraska. The differences may be on account of variances in hydrology across settings or social norms among irrigators, but also due to the econometric challenges of addressing simultaneity bias and spatial correlation of unobservable characteristics.

Regardless of the past and current externality estimates, the losses from unregulated pumping will worsen over time. For one, the gains from optimal control are predicted increase as groundwater becomes more scarce (Koundouri 2004a). Furthermore, because of population growth and climate change, the expectation is that irrigators will increasingly rely on groundwater resources (Richey et al. 2015; Taylor et al. 2013; Gleick 2010). The pattern may have already emerged, especially within the United States where total groundwater depletion increased in the first decade of the new century, more than doubling the depletion observed in the 1980s and 1990s (Konikow 2013). Even more recently, during California's prolonged drought, irrigators there have increasingly turned to groundwater to replace the lacking snowmelt, though are now confronting the task of implementing their own local groundwater management plans.

In light of the growing evidence of inefficient use along with the projected increase in demand, groundwater regulations are increasingly debated and implemented. Where groundwater-pumping impacts surface right holders, wells may be forced to shutdown entirely because they are out of priority. ${ }^{3}$ Controlling well density can make property rights to groundwater relatively more complete by reducing the interaction of competing cones of depression, ultimately allowing irrigators to approach groundwater use more like sole-owners which may lead to more conservation (Edwards 2016). Similarly, requiring

\footnotetext{
3 The prior appropriation doctrine allocates water during shortages based on date of first use. Because wells generally developed after surface water, they are the most junior under conjunctive management.
} 
or subsidizing more efficient irrigation technology offers a potential way to reduce pumping. But both spacing requirements and adoption of more efficient technology can undermine conservation if irrigators use the gains to switch to more water intensive crops, like corn over parts of the High Plains Aquifer (Peterson \& Ding 2005; Pfeiffer \& Lin 2014; Edwards 2016). Along with environmental externalities more broadly, there are potential efficiency gains in implementing an economic-based incentive rather than control-and-command interventions (Goulder \& Parry 2008). However, few examples for groundwater conservation exist as of yet. In Nebraska, along the Republican River Basin, tradable pumping rights have been implemented to reduce the compliance cost of pumping reductions (Brozović \& Young 2014).

Like tradable permits, a pumping tax introduces a price and an incentive to reduce groundwater use. The theoretical appeal of inducing economic and technological efficiency has long been recognized in the groundwater setting and continues to be suggested (Brown \& Deacon 1972; Zilberman et al. 1997; Koundouri 2004a). However, there are doubts about the effectiveness of a tax. For one, the administrative costs may be high and if the gains are relatively small, it may not be worth the effort (Feinerman \& Knapp 1983). Second, a tax leaves open ended the reduction that will be realized. Given work on the price elasticity of water demand, generally between -0.03 and -0.40 , the change in pumping from a change in price is expected to be somewhat low (see Koundouri (2004a) and Scheierling et al. (2006) for reviews). Some more recent research, using panel data and instrumentation for endogenous crop and technology choices, suggests that water demand may be more elastic, around -0.79 (Schoengold et al. 
2006). However, the implementation of a tax is not a marginal price increase and may result in a different response.

Regardless, the sparse empirical analysis of actual taxes has been equally pessimistic. Imposing a tax on water use was insufficient to induce conservation in both the Netherlands and China (Schuerhoff et al. 2013; Yang et al. 2003). In contrast, (Smith et al. 2018) finds a rather large reduction following the implementation of a pumping tax in the SLV (discussed in more detail below), greater than what has been implied by the extant literature. It is this case that this study analyzes to assess whether the decrease is completely attributable to the direct increase in costs of the tax or in part due to social norms towards conservation crowded in by the tax.

\subsection{San Luis Valley Irrigation}

Nestled between the Sangre de Cristos and San Juan Mountains in Southern Colorado, the SLV forms the largest inter-mountain park in the world at 8,300 square kilometers (Weiler \& Seidl 2004). Because of the fertile soil, much of land in SLV is dedicated to agriculture. In 2012, agriculture in the Valley generated over $\$ 300$ million of revenue (U.S. Department of Agriculture 2012), around 33 percent of total economic activity. The aridity of the region (around 10 inches of precipitation annually) requires farmers to irrigate with supplemental water; over 95 percent of cropland has been irrigated historically. Dating back to 1852 , irrigators relied on snowmelt from the surrounding peaks to supply water. An expansive system of surface water ditches, numbering over 400 , continues to convey snowmelt today subject to supply and the prior appropriation doctrine, which provides water to ditches based on date of initial diversion. 
Groundwater development began to complement the surface water sources in the 1950 s. Cropland in SLV overlays two aquifers, one confined and the other unconfined. Spurred by relatively cheap energy, new sprinkler technology, and a series of drought years in the 50s, junior irrigators first installed wells to provide resilience. Soon, though, even senior water right irrigators developed wells to draw on the additional water; from 1950-1960, the region expanded from 808 wells to 2,704. Expansion continued, though more slowly, through 1969 when Colorado issued a moratorium on any new large capacity wells. The roughly 3,500 wells that were built, though, mostly remain in use today and irrigators rely on groundwater more than surface water and the area boasts the densest development of crop circles today. The aquifer system is complex and it is not yet well understood how water moves around, but Bexfield \& Anderholm (2010) a good overview on the hydrology. Notably, the aquifer exhibits high transmissivity (up to $2,800 \mathrm{~m}^{2} /$ day), suggesting the groundwater migrates relatively freely.

Data on total storage in the aquifer is not known, but monitoring since 1976 has provided a record for the change in storage. From 1976 through 2002, the aquifer remained stable on average, in part due to an unusual string of wet years in the 1980s. ${ }^{4}$ The equilibrium, however, was disrupted in 2002 when snowpack in April was only 6 percent of average. Because groundwater extraction remained unregulated, the irrigators simply pumped more. While not as severe as 2002 , the first part of the new century has been punctuated

\footnotetext{
4 According to irrigators, during the 1980s the larger issue was getting rid of water as fields became saturated.
} 
by many disappointing snowpack years. As a result, aquifer storage fell by over $1,000,000$ acre-feet since $2002 .^{5}$

Irrigators not only recognized their collective unsustainable groundwater extraction, but also faced the threat of state intervention, likely in the form of individual regulation. With a history of self-determination and successful collective action, the irrigators chose to come up with a local solution (Cody et al. 2015). To make the endeavor manageable, the region was divided into 6 subdistricts with each tasked to create their own rules. Subdistrict 1 (henceforth "the subdistrict") began talks in 2006 and created a set of rules that went into affect in 2011. Within the subdistrict the irrigators chose an economic incentive to deter excess pumping. Specifically, they adopted a pumping tax to be set each year between $\$ 0$ and $\$ 75 / \mathrm{AF}$. In 2011 it was set at $\$ 45$ and then increased to $\$ 75$ for both 2012 and 2013. ${ }^{6}$ Meanwhile, the other subdistricts remain in the process of developing their own rules with Subdstrict 2 officially beginning operation in 2016. Notably, the other subdistricts are also adopting pumping fees and were only delayed due to the scarcity of legal and technical resources necessary to develop subdistrict management schemes. These resources were focused on Subdistrict 1 initially because it is the largest and has the greatest impact on the flow of Rio Grande, hurting both a large number of Colorado surface right holders and imperiling Colorado's ability to meet its obligations to New Mexico and Texas from the Rio Grande Compact.

The impact of the intervention is important to understand as few price systems have been implemented for groundwater extraction. As discussed above, it is not clear that the tax

\footnotetext{
5 AF-an acre-foot is the amount of water to submerge 1 acre in 1 foot of water, or 325,851 gallons.

6 The rate remained at \$75/AF for 2014 and 2015 but relevant data for analysis are not yet available.
} 
would elicit a large change in behavior. Figure 1, showing annual pumping by farm units in SLV, provides suggestive evidence that the intervention has indeed reduced pumping within the subdistrict; the response is even greater if compared to pumping patterns outside of the subdistrict, but within SLV. In a more formal analysis, (Smith et al. 2018) found that irrigators have reduced groundwater pumping per unit of land by 30 percent. In addition, irrigators have shifted away from flood irrigation, and, in contrast to technology adoption absent increased marginal costs, also shifted away from alfalfa production towards crops demanding less water. It is the overall reduction, arguably larger than the economic incentive would imply, that suggests the economic price may have crowded-in conservation norms.

\subsection{Crowding-in Mechanism}

In the case of groundwater extraction, the actors play both roles, both inflictors and recipients of the external costs. In a simple framework, irrigators face a prisoner's dilemma: they are aware that conserving water is the social optimum, but they have an incentive to not conserve groundwater no matter the behavior of the other irrigators, at least in a static framework. However, because the game is repeated each year, much equilibria exist and it is not apparent that the sub-optimum outcome is inevitable. With a large number of extractors and no regulation it is also not clear that they will avoid the sub-optimum outcome.

By adopting a price, the users have shifted up the marginal cost curve, meaning the payout structure has changed and users should pump less water on economic grounds. The crowding literature generally suggests that any conservation that occurred before 
may be crowded out. I instead suggest that the price may crowd-in conservation by acting as a commitment signal. Because the tax is internally imposed, not externally, the adoption communicates to all users that the other users are committed to achieving a better equilibrium (Vyrastekova \& Soest 2003). In other words, the price indicates that fellow irrigators are more likely to conserve more. Further, for the conditional cooperators, the fee may erode there need for retaliation (by over pumping), creating a larger group of unconditional cooperators (Rode et al. 2014; Narloch et al. 2012; Rodriguez-Sickert et al. 2008). I now turn to the data to analyze conservation behavior and the impact of the groundwater tax.

\section{Data}

The Colorado Decision Support System (CDSS), a subset of the Colorado Division of Natural Resources, makes all data utilized in this analysis publicly available. In addition to spatially oriented water structure data, structure-year specific water use measures gathered through bulk downloads from HydroBase (a CDSS data tool) constitute the majority of the data used for analysis.

Beginning in 2009, meters were installed on most wells in SLV and annual pumping records (in AF) for 3,472 wells are available from the CDSS though the final sample for analysis based on complete records is reduced to 3,057 wells. Pumping data for this and related research has been gathered and cleaned through the 2013 irrigation season. Identified by a unique water district identification number (WDID), the pumping data are linked to a number of well specific characteristics, including the permitted flow (in cubic feet per second-cfs), well depth, and physical coordinates. Each year the wells are linked 
to second spatial database of irrigated parcels, allowing for the identification of acreage served and technology used (flood or sprinkler). Because parcels sometimes are served by more than one well and wells sometimes serve more than one parcel I adjust the parcel data accordingly, also maintaining a measure of how many parcels a well serves.

As mentioned above, SLV irrigators rely on surface water as well. Allocation of the annual snowmelt is determined by the prior appropriation doctrine, providing senior right holders their full allotment prior to junior right holders receiving any. With little surface storage and a use-it-or-lose-it element of the law, excess surface water is not available and the increased groundwater costs will not cause an increase use in surface water. However, more surface water may lead to a decrease use of groundwater. For each year I have collected data on the total acre-feet diverted by surface ditches and know which irrigated parcels were served. Division within a ditch among parcels is unobservable, so I simply assume total supply is spread evenly across the land. For groundwater height, I use monitoring wells throughout the region and interpolate height at each well in ArcGIS. Some wells are outside of the interpolation and the number of observations with groundwater height is slightly smaller.

The spatial nature of the data allows for the construction of additional and important variables. First, using ArcGIS I are able to assign wells to the subdistrict. Second, I are able to calculate the distance between any two wells. By then matching this to pumping records, I create a total pumping by nearby wells measure by summing all pumping within various radii. Further, I attempt to distinguish by whether the nearby well is owned by the same owner or someone else. Without data on current ownership, I are unable to link all wells accurately. Instead, I rely on observational data and an iterative 
grouping process, creating farm units based on linking wells across all shared parcels and shared wells and time. The process unlikely produces many false positives (links identified are likely linked), but will under identify farm units where parcel-well combinations are one-to-one. Therefore some "own" pumping remains attributed to neighbors. ${ }^{7}$

Table 1 provides summary statistics for the variables and observations in the main analysis. Over the entire period, wells pump $137 \mathrm{AF}$ of groundwater per year on average. Furthermore, the configuration is relatively dense. Within 0.25 miles of a well, 1,024.69 AF of water is extracted by others' wells each year. On average, 7.3 wells owned by others are within this range. This density is much greater than on the Ogallala aquifer where Pfeiffer and Lin (2012) report only 0.6 wells within 0.5 miles on average. Within a quarter mile of wells in the SLV, wells operated by the same person are pumping 53.56 AF on average. ${ }^{8}$

Decreed rate of flow for a well comes from permit data and is denominated in cubic feet per second; across the current wells the average permitted flow is 2.44 CFS. This amount is fixed for the well and does not vary over time. The subdistrict indicator variable is 1 for 70 percent of the sample, meaning more wells are observed within the subdistrict $(2,117 /$ year) than outside (926/year). The average fee $(\$ 27.14 / \mathrm{AF})$ varies only by year and membership of the subdistrict. Well depth, measured in feet below surface, is 212.96 feet, but highly variable. Wells serve around 1.62 parcels on average. After dividing

\footnotetext{
${ }^{7}$ If owners are more likely to consider externalities imposed by their pumping at one well on another of their wells, the error will lead to an underestimate of pumping in response to neighbors' pumping.

8 The average pumping by other wells owned by the same person is lower because there are fewer of them. Further, because of many "zero" observations, the average pumping amount is considerably lower than the average pumping of any given well.
} 
parcels by the number of wells used and then adding up this value across all parcels served by a single well, each well irrigates 80.99 acres on average. Sprinkler technology is dominant, accounting for 85 percent of the wells. Last, groundwater height is on average 7,608.32 feet above sea level (the Valley floor is 7,700 feet on average).

\section{Influence of Pumping on Groundwater Height}

Because aquifers differ, and are almost certainly misrepresented by the bath-tub model, it is important to understand the extent of lateral flow empirically: How much does pumping by well $i$ impact the groundwater height at well $i$, and how much does nearby pumping do the same? This provides some sense of how incomplete the property rights are over the groundwater. In order to do so, I run a simple OLS estimate for the following equation:

$\Delta G W H_{i t}=\beta_{1} W_{i t}+\beta_{2} \sum_{j \in(0, u b)} W_{j t}+\beta_{3} \sum_{s \in(0, u b)} W_{s t}+\delta^{\prime} X_{i t}+\boldsymbol{\tau}_{t}+\varepsilon_{i t}$

The dependent variable is the change in groundwater height from last year to year $t$. The right-hand variables of interest are pumping by various wells: $W_{i t}$ is pumping at the well itself, $\sum_{j \in(0, u b)} W_{j t}$ is cumulative pumping by wells in the radius defined by the upper bound $(u b)$ but not owned by the same owner of well $i$, and $\sum_{s(0, u b)} W_{s t}$ are those within the radius owned by the same irrigator. Additional covariates $\left(\boldsymbol{X}_{i t}\right)$ are limited to surface water availability as a measure of potential recharge. Year fixed effects $\left(\boldsymbol{\tau}_{t}\right)$ are included as well.

The results are presented in Table 2. Each column reports regressions in which the neighborhood considered gets progressively larger moving left to right. Accordingly, 
only the coefficients on the two variables sensitive to the range should be expected to change substantially. As expected, pumping at the well in question reduces groundwater height, about 0.00361 feet. Given that average pumping is $137 \mathrm{AF} / \mathrm{year}$, this lowers groundwater by 0.50 feet over the year. Pumping an additional acre-foot by a well within 0.25 miles also lowers the water table, but by a smaller marginal amount ( 0.000551 feet). Notably, this coefficient gets smaller as wells further and further out are added, indicating that wells closer are more readily able to capture unused water. And while the marginal effect of pumping nearby is smaller than pumping at the actual well, given the average aggregate amount of pumping within a quarter mile (1027.23 AF), the total effect of nearby pumping is larger, reducing the water table by 0.57 feet. The mere presence of large lateral flows indicates that property rights over groundwater are far from complete and the external costs may contribute to over-extraction.

\section{Preliminaries}

\subsection{Overall Impact of the Intervention}

Before disentangling direct and indirect effects, I first consider the overall impact the tax. Similar to Smith et al. (2018), I adopt a difference-in-difference framework, but conduct analysis at the well level rather than some unit of irrigated land. Specifically, I estimate:

$W_{i t}=\alpha_{1}+\alpha_{2} \times$ Subdistrict Post $_{i t}+\alpha_{3} \times$ Subdistrict $_{i t}+\delta^{\prime} \boldsymbol{\omega}_{i t}+\tau_{t}+\delta_{d}+\varepsilon_{i t}$

$W_{i t}$ is acre feet extracted at well $i$ in year $t$. The coefficient of interest is $\alpha_{2}$, capturing the effect of being a well within the subdistrict once the financial incentives are put in place, from 2011 on. As alternative methods, I also replace that indicator variable with the actual fee amount as well as a $\log -\log$ specification, using $\log ($ fee +40$)$, where 40 is 
assumed to be the average marginal pumping cost. Subdistrict ${ }_{i t}$ is an indicator for being a well within the subdistrict borders. Additional covariates $\left(\boldsymbol{\omega}_{i t}\right)$ include surface water supplied, ${ }^{9}$ number of parcels served, acreage irrigated, technology used, well depth, permitted flow, and latitude and longitude. In addition, year fixed effects $\left(\tau_{t}\right)$ and surface ditch fixed effects $\left(\delta_{d}\right)$ - with no surface water as the omitted group - are included.

The results, shown in Table 3, are consistent with the analysis in Smith et al. (2018): wells subject to the subdistrict rules reduce groundwater extraction by 66.49 acre-feet on average. If attributable fully to the financial portion of the intervention, each additional dollar charged per acre-foot yielded a reduction of 0.952 acre-feet extracted over the course of the year. Using the log-log specification, the reduction would correspond to a price elasticity of -0.71 .

\subsection{Spatial relationships}

However, the analysis does not explicitly consider spatial relationships despite the externality being spatially explicit and the response appears to be heterogeneous across space. For instance, in Figure 2, I map the change in observed average pumping from the pre-treatment years to the post-treatment years within the subdistrict at each well. There appear to be clusters of wells that are similar in their changes. To more formally test this visual observation, I run the simple cross-sectional regression:

$$
\Delta \overline{W_{l}}=\beta_{1} \Delta \overline{\sum_{\jmath \in(0, u b)} W_{J}}+\delta^{\prime} \boldsymbol{\theta}_{i}+\varepsilon_{i}
$$

\footnotetext{
9 This includes interaction terms (pre- and post-treatment) with surface ditches that have a special decree for groundwater recharge as a beneficial use.
} 
That is, I regress the change in average pumping at well $i$ on the total change in average pumping by those wells within a certain radii of well $i$. Additional covariates here include well depth, permitted flow, and latitude and longitude. The results in Table 4, reporting regressions only for subdistrict wells, show that their does exist a positive correlation between how much neighbors' change their pumping and your own. Furthermore, the relationship is reduced the as more distant wells are considered. This is suggestive spatial factors are important. This specific result may not have to do with social-norms and could be driven by physical factors that lead some areas to be more responsive than others to a change in extraction costs.

The question is whether irrigators in SLV pump relatively more in response to additional pumping by their neighbors? Before empirically testing for this behavior, it is important to consider whether it is practical to believe that they could. Specifically, to respond to your nearby pumping requires knowledge of nearby pumping. Prior to 2009, fewer than 10 percent of SLV wells had meters. Even after 2009, the extraction was not continuously measured and reported. Still, it is reasonable that neighbors would have an idea of water usage by their neighbors if not exact amounts. One, as shown above, nearby pumping does reduce groundwater levels, meaning data on that pumping is physically transmitted. Second, irrigation technology, crop choice, and acreage planted are all highly observable and indicative of how much water will likely be used. For instance, potatoes, essentially sacks of water, are not forgiving to water shortages and will require a minimum amount of water-per-acre. The local farmers have a firm understanding of what it takes to grow a given acreage of a given crop in terms of water needed. Third, neighbors can observe active sprinklers - when and how long they are running - updating the estimates created 
from the discrete planting choices. For alfalfa fields, for instance, it would be readily apparent whether a neighbor is applying more water to get a second or even third cutting.

To test whether SLV irrigators alter than own behavior in response to this nearby pumping, I consider the following regression model:

$W_{i t}=\beta_{1} \sum_{j \in(0, u b)} W_{j t}+\beta_{2} \sum_{s \in(0, u b)} W_{s t}+\delta^{\prime} \boldsymbol{\omega}_{i t}+\tau_{t}+\delta_{d}+\varepsilon_{i t}$

The additional covariates are as defined above for equation (2). OLS coefficient estimates for nearby pumping are presented in Table 5. Within a quarter mile, an additional acrefoot extracted is associated with an additional 0.00696 acre-feet at the well, which would explain 7.15 acre-feet in total. If taken literally, this would suggest 5.2 percent of annual pumping at a well is in response to nearby pumping. Estimating equation (3) by OLS, however, is problematic. If well $j$ is within the specified distance range from well $i$, then well $i$ will also be in that distance range for well $j$. Estimation, therefore, is difficult because the simultaneity endogoneity bias means $\operatorname{cov}\left(W_{i t}, \varepsilon_{i t}\right) \neq 0$ and estimates will be biased. In the spirit of Pfieffer and Lin (2012), I adopt an instrumental variable approach, utilizing the permitted flow of well $j$ to provide exogenous variation for nearby pumping. Accordingly, for the first stage I estimate equation (5) - specified below - by OLS, and then repeat for nearby pumping by wells owned by the same irrigator.

$\left(\sum_{j \in(0, u b)} W_{j t}\right)_{i t}=\alpha_{1} \sum_{j \in(0, u b)}$ permit $_{j}+\alpha_{2} \sum_{s \in(0, u b)}$ permit $_{s}+\delta^{\prime} \boldsymbol{\omega}_{i t}+\tau_{t}+\delta_{d}+\rho_{i t}$

With predicted values for pumping nearby, I are able to estimate a version of equation (2) using predicted values from the first stage. For the instrument to be valid it must sufficiently predict actual pumping and plausibly meet the exclusion restriction. Table 6 provides the results from estimating equation (5) directly. Across all radii, the effect is 
similar with another cubic-foot per second being permitted resulting in another 19.74 acre-feet being extracted. Furthermore, the t-statistic for the permitted flow is large and the F-stat for exclusion is around 136, well above the typical threshold. Accordingly, I am confident of the instrument's relevance. Satisfying the exclusion principle cannot be as formally tested and requires more consideration.

In a simple thought experiment, the instrument seems viable; a neighbor's permitted flow should not impact my pumping other than through the impact it has on their actual pumping. This is particular true because the permit is a flow, meaning a well could pump more or less volume by altering how long they are willing to pump. However, the permits themselves may not be entirely exogenous and the spatial distribution of permitted amounts may be correlated. In an ideal world (for the researcher), decreed flows would be randomly assigned. In reality, permits are determined in part by the expectation of groundwater production. This means that permits are in part determined by the physical attributes of the area, which tend to be correlated in space. In general, the permits within and beyond the subdistrict do exhibit some positive spatial correlation.

To interpret the two-stage least square estimates as causal, however, requires only that the permitted flow (the instrument) is random given the covariates. This is important because I am able to include permitted flow at well $i$ as an additional control. Therefore, the variation I am using is that beyond the average spatial correlation, which is much more likely to be random. According to the Colorado State Engineer (by personal correspondence), a driller would determine the decreed amount during a pumping test. Importantly, not all tests are equal. Many times the test was done with a test pump and not the actual pump to be used. In addition, there was no set length of time, meaning 
some were lengthy, 8-10 hours, providing a more accurate measure, while others were as short as an hour, leading to some inaccuracy. On net, then, variation beyond the average spatial correlation appears can be attributed to randomness, whether due to inconsistent methods of pumping tests, idiosyncratic pump technology choices, or if the aquifer, for physical reasons, happens to be slightly easier or harder to access.

A simple regression indicates that once I control for the covariates, nearby aggregate permitted flow is not correlated with individual well permits. Table 7 provides the regressions results for a between-effects analysis based on following equation:

permit $_{i}=\delta_{1} \sum_{j \in(0, u b)}$ permit $_{j}+\alpha_{2} \sum_{s \in(0, u b)}$ permit $_{s}+\delta^{\prime} \boldsymbol{\omega}_{i t}+\tau_{t}+\delta_{d}+\varphi_{i}$

The results strongly indicate that, conditional on the set of covariates (excluding permitted flow at well $i$ since this is the dependent variable), permits are not spatially correlated. Interestingly, there does exist some negative correlation with other wells owned by the same irrigator, suggesting these wells may serve complementary roles to one another. On net, it appears the permitted flow provides a valid instrument.

Using two-stage least squares to re-estimate equation (4) I find no causal effect of nearby pumping on pumping at a given well on average. Reported in Table 8 , the coefficients across all radii are no longer positive or statistically significant. This analysis, however, may obscure any distinctive behavioral responses between those inside the subdistrict and those outside, and, more importantly, before and after the intervention. Next, I present the main analysis that is designed to isolate the impact of the intervention, distinguishing the shift due directly to the financial incentive and the indirect effect of crowding-in social norms. 


\section{Methods}

In order to assess the impact of the intervention, I adopt a difference-in-difference framework. I utilize the wells outside of the subdistrict, but within SLV, as a counterfactual to proxy for any general trend and look at pumping before and after the intervention. The natural experiment follows Smith et al. (2018) but differs in three important ways. First, the analysis is conducted at specific wells rather than by land units. Second, rather than an indicator variable for treatment, I primarily utilize the dollar amount of the fee. Last, and most importantly, I fully interact the difference-in-difference framework (using only indicator variables) with neighbor pumping at various distances. The estimating equation is as follows:

$W_{i t}=\beta_{1}$ Fee $_{i t}+\beta_{2} \sum_{j \in(0, u b)} W_{j t} \times \operatorname{Subd}_{i t} \times$ post $_{t}+\beta_{3} \sum_{j \in(0, u b)} W_{j t}+\beta_{4} \sum_{j \in(0, u b)} W_{j t} \times S u b d_{i t}+$ $\beta_{5} \sum_{j \in(0, u b)} W_{j t} \times$ post $_{t}+\beta_{6} \sum_{s \in(0, u b)} W_{s t}+\beta_{7} \operatorname{Subd}_{i t}+\delta^{\prime} \boldsymbol{\omega}_{i t}+\boldsymbol{\tau}_{t}+\delta_{d}+\varepsilon_{i t}$

The direct effect of the financial intervention is captured by $\beta_{1}$ while $\beta_{2}$ is the estimated indirect effect as transmitted through a change in behavior relative to nearby pumping. As before, estimation is done by two-stage least squares using permitted flows to instrument for nearby pumping. Notably, rather than imposing a constant relationship between permitted pumping and nearby pumping, a separate instrument is used for all the interactions. That is, rather than predicting nearby pumping by nearby permits once and then interacting the predicted values, I interact the instruments themselves and run four first stage equations (and a fifth for nearby pumping by the same owner of well $i$ ) to predict the values. This way nearby irrigators are allowed to behave differently in 
response to their own permitted flow across district borders and pre- and postintervention.

In order to interpret the resulting coefficient estimates as causal, irrigators within the subdistrict would needed to have shared a trend with those outside absent the intervention. Inherently untestable, often evidence of a similar trend pre-intervention is used to substantiate the assumption. Returning to Figure 1, overall pumping trends do appear similar prior to 2011. Evidence in Smith et al. (2018) established with statistical evidence that the trends were indistinguishable. However, for the current analysis it is important that both groups follow a similar trend in their reaction to nearby pumping. To test this assumption, I estimate equation (7) but only for 2009 and 2010, replacing post $t_{t}$ with an indicator for 2010. Because this is pre-intervention, I would expect that the relative change from 2009 to 2010 should be the same. Results are reported in the appendix, Table A1, and show no distinguishable difference in the trend. Therefore, unable to reject the null hypothesis that the treated group was following a different trend than the control group pre-treatment, it is plausible to assume that they would have continued to do so.

\section{Results}

Piecing the entire model together, regression results for equation 7 - with instrumental variables for nearby pumping - are reported in Table 9 (Table A2 of the appendix provides estimated results by OLS for comparison).10 The estimates indicate that part of

\footnotetext{
10 Given the interaction terms with the difference-in-difference framework, signing the bias is not unambiguous. The bias of the interaction term would depend on the direction and magnitude of the bias of the main effect as well as the interaction with post-intervention and subdistrict wells.
} 
the total reduction is in part due to reduced pumping related to neighbors' pumping. The impact is largest for pumping within 0.25 miles, where subdistrict irrigators have reduced their own pumping by 0.0155 AF for each AF of pumping within that range. Given average pumping characteristics, this would account for 16 fewer AF pumped each year. This conservation is on top of the direct impact of the fee, which is reduced in magnitude slightly (to $-0.830 \mathrm{AF} / \$$ ) compared to the estimates in Table $3(-0.952)$. The smaller impact of the fee is consistent with the spatial crowding-in component being picked up by the fee itself when omitted.

Expanding the range all the way to three miles, the marginal reaction to nearby pumping is reduced to -0.00241 , consistent with pumping further away having a weaker relationship in general. Using some back-of-the-envelope calculations, I can calculate the direct and indirect effect of the fee. The aggregated effect of nearby pumping within 3 miles is a 29.5 AF reduction based on an average of 12,230.23 AF within that range. In the three-mile specification, the direct impact of the fee is estimated to be $-0.717 \mathrm{AF} / \mathrm{\$}$. Over the course of the three years, the average fee is $\$ 65 / \mathrm{AF}$, meaning a reduction of 46.61 AF can be attributed directly to the fee. Though it is possible pumping beyond three miles should be considered, simply adding the direct effect and the indirect effect estimated in column 5 brings about a total reduction of $76.11 \mathrm{AF}$. This total reduction is very close to the estimate in Table 3 , column 1 (66.5 AF) when the distinction was not made, providing some internal validity. The size of effects suggest that the fee accounts for the largest portion of the reduction, 61 percent, but that the change in pumping response accounts for a non-negligible share, 39 percent. 
Alternative specifications of equation (7) are considered to address potential concerns that the spatial relationship is not attributable to a change in social norms. First, I add groundwater height as a covariate. Though this is the avenue through which nearby pumping inflicts external costs at a given well, a change in the physical costs, not behavioral change, may lead to the reduction in pumping that I observe. In other words, I may observe less pumping in response to nearby pumping after the intervention because the aquifer level is being drawn down further by the nearby pumping and increasing pumping costs. Table 10 allays this concern to some degree, as the main results remain robust even when explicitly including groundwater height as a control. Furthermore, the point estimates on groundwater height itself is positive, consistent with lower marginal lift costs when groundwater height is higher. Additional robustness checks are included in the appendix.

\section{Conclusion}

On net, I find that the fee did reduce pumping considerably, and that some of the reduction is attributable to a shift in social norms towards conservation. Even though irrigators were not aggressively competing for water prior to the intervention, following the intervention they further increase their own conservation relative to nearby pumping. This is important in the general sense, that economic prices can crowd-in social norms rather than crowding them out. It is likely that that the dual role and symmetry between the irrigators played a role; they were both the inflictors and recipients of externality. Because of this, the adoption of the of pumping fee provided a credible commitment 
device to move towards a better social outcome, resulting in reductions beyond what the actual financial incentives would lead to. ${ }^{11}$

It may be that the crowding-in effect I identify is a lower bound. For one, I imposed a spatial relationship on the conservation behavior when there may have been shifts even more generally. Second, if the internal process of agreeing upon a mechanism to reduce pumping can explain the shift in social norms, that process began in 2006 , before any pumping data was available. Likewise, wells excluded from this subdistrict (forming our control group) have begun their own conversations, perhaps inducing a shift in their social norms even prior to the implementation of rules. This would also lead us to underestimate the crowding-in effect I found. Accordingly, if the conservation grew throughout that process as trust was built, some shift in social norms had already occurred. Regardless, the implementation of the tax appears to have accented any shift in social norms that were occurring, meaning the price gave credibility to the conservation idea that simple discussion did not. I hypothesize that the adoption of tradable permits would not have the same crowding-in effect; even though a price provides a signal, an irrigator that conserves more will likely sell the permit, meaning someone will extract the groundwater. Essentially, there is unlikely to be any conservation beyond the limit imposed by the total permitted amount.

Two important and related questions remain. First, when can the introduction of prices be expected to crowd-out social norms or crowd them in? The answer remains beyond the scope of this paper, though I can consider the scenario to develop hypotheses. For

\footnotetext{
${ }^{11}$ It should be noted that no welfare analysis is conducted. Accordingly I cannot definitively show that the reduction in pumping, given the fee, is a better equilibrium.
} 
instance, the internal process stands out. Often crowding-out is based on an external intervention being imposed. And though some irrigators opposed the form of the subdistrict rules, by and large the irrigators imposed the fee on themselves. In other words, whether tax was external or internal motivation - often the terms used to distinguish regulation from moral behavior - depends on the unit of analysis.

The second question that remains then, is how effective is a groundwater tax in changing pumping behavior. In other words, was it the internal process, the use of a price, or the combination? Though in this instance I found a substantial reduction, it is not clear that policy makers should impose taxes elsewhere expecting a similar response. Not only do the physical realities of aquifers differ across sites, but irrigators also vary. In addition, an externally imposed tax may be less likely to bring about a crowding-in effect. If an external tax crowds-out any existing conservation behavior it would be even more problematic.

Meanwhile, a local collaborative process that does not result in financial incentives may be less likely to increase conservation. Without a commitment to prices, the communications and agreements could be viewed as cheap talk that does not provide users a collective confidence of cooperative behavior in future periods, eroding conservation now. Policymakers should, however, consider the crowding results that are made possible if the aquifer users are encouraged to adopt their own rules, where the process can shift behavior independent of, and likely interacted with, the final set of rules they settle on. 


\section{References}

Abatayo, A. Lou \& Lynham, J., 2016. Endogenous vs. exogenous regulations in the commons. Journal of Environmental Economics and Management, 76, pp.51-66. Available at: http://linkinghub.elsevier.com/retrieve/pii/S0095069615000923.

Bexfield, L.M. \& Anderholm, S.K., 2010. Conceptual Understanding and Groundwater Quality of the Basin-Fill Aquifer in the San Luis Valley, Colorado and New Mexico. In Conceptual Understanding and Groundwater Quality of Selected Basin-Fill Aquifers in the Southwestern United States. pp. 165-187. Available at: http://pubs.usgs.gov/pp/1781/pdf/pp1781_section10.pdf.

Bolle, F. \& Otto, P., 2010. A price is a signal: On intrinsic motivation, crowding-out, and crowding-in. Kyklos, 63(1), pp.9-22. Available at: http://onlinelibrary.wiley.com/doi/10.1111/j.1467-6435.2010.00458.x/full.

Bowles, S., 2008. Policies designed for self-interested citizens may undermine "The Moral Sentiments": Evidence from economic experiments. Science, 320(5883), pp.1605-1609. Available at: http://www.sciencemag.org/cgi/doi/10.1126/science.1152110.

Brill, T. \& Burness, H., 1994. Planning versus competitive rates of groundwater pumping. Water Resources Research, 30(6), pp.1873-1880. Available at: http://onlinelibrary.wiley.com/doi/10.1029/94WR00535/full.

Brown, G. \& Deacon, R., 1972. Economic optimization of a single-cell aquifer. Water Resources Research, 8(3), pp.557-564. Available at: http://doi.wiley.com/10.1029/WR008i003p00557.

Brozović, N., Sunding, D.L. \& Zilberman, D., 2010. On the spatial nature of the groundwater pumping externality. Resource and Energy Economics, 32(2), pp.154164.

Brozović, N. \& Young, R., 2014. Design and implementation of markets for groundwater pumping rights. In K. W. Easter \& Q. Huang, eds. Water Markets for the 21st Century. Global Issues in Water Policy. Dordrecht: Springer Netherlands, pp. 283303. Available at: http://link.springer.com/10.1007/978-94-017-9081-9.

Capoor, K. \& Ambrosi, P., 2008. State and trends of the carbon market 2008. Available at: https://www.openknowledge.worldbank.com/handle/10986/13404.

Cardenas, J.-C., 2000. How do groups solve local commons dilemmas? Lessons from experimental economics in the field. Environment, Development and Sustainability, 2, pp.305-322.

Cody, K.C. et al., 2015. Emergence of collective action in a groundwater commons: Irrigators in the San Luis Valley of Colorado. Society \& Natural Resources, 28(4), pp.405-422.

Convery, F., McDonnell, S. \& Ferreira, S., 2007. The most popular tax in Europe? Lessons from the Irish plastic bags levy. Environmental and Resource Economics, 38(1), pp.1-11.

Deci, E., Koestner, R. \& Ryan, R., 1999. A meta-analytic review of experiments 
examining the effects of extrinsic rewards on intrinsic motivation. Psychological bulletin, 125(6), pp.627-668. Available at: http://psycnet.apa.org/journals/bul/125/6/627.

Edwards, E.C., 2016. What lies beneath? Aquifer heterogeneity and the economics of collective action. Journal of the Association for Environmental and Resource Economists, 3(2), pp.453-491.

Engel, S., Pagiola, S. \& Wunder, S., 2008. Designing payments for environmental services in theory and practice: An overview of the issues. Ecological economics, 65, pp.663-674. Available at: http://www.sciencedirect.com/science/article/pii/S0921800908001420.

Feinerman, E. \& Knapp, K.C., 1983. Benefits from groundwater management: magnitude, sensitivity, and distribution. American Journal of Agricultural Economics, 65(4), pp.703-710. Available at: http://www.jstor.org/stable/1240458.

Frey, B.S., 1994. How Intrinsic Motivation is Crowded Out and In. Rationality and Society, 6(3), pp.334-352.

Gisser, M. \& Sanchez, D.A., 1980. Competition versus optimal control in groundwater pumping. Water Resources Research, 16(4), pp.638-642.

Gleick, P.H., 2010. Roadmap for sustainable water resources in southwestern North America. Proceedings of the National Academy of Sciences, 107(50), pp.2130021305.

Gneezy, U. \& Rustichini, A., 2000. Fine is a price, a. J. Legal Stud., 29(1), pp.1-17. Available at: http://heinonlinebackup.com/hol-cgibin/get_pdf.cgi?handle=hein.journals/legstud29\&section=7.

Goulder, L.H. \& Parry, I.W.H., 2008. Instrument choice in environmental policy. Review of Environmental Economics and Policy, 2(2), pp.152-174.

Guilfoos, T. et al., 2013. Groundwater management: The effect of water flows on welfare gains. Ecological Economics, 95, pp.31-40. Available at: http://www.sciencedirect.com/science/article/pii/S092180091300253X.

Hardin, G., 1968. The tragedy of the commons. Science, 162(3859), pp.1243-1248. Available at: http://www.sciencemag.org/content/162/3859/1243.full.pdf\&quot;\&gt;

Huang, Q. et al., 2013. The effects of well management and the nature of the aquifer on groundwater resources. American Journal of Agricultural Economics, 95(1), pp.94116.

Kerr, J., Vardhan, M. \& Jindal, R., 2012. Prosocial behavior and incentives: Evidence from field experiments in rural Mexico and Tanzania. Ecological Economics, 73, pp.220-227. Available at:

http://linkinghub.elsevier.com/retrieve/pii/S0921800911004605.

Konikow, L.F., 2013. Groundwater depletion in the United States (1900-2008), US Department of the Interior, US Geological Survey. Available at: http://pubs.usgs.gov/sir/2013/5079.

Koundouri, P., 2004a. Current issues in the economics of groundwater resource 
management. Journal of Economic Surveys, 18(5), pp.703-740. Available at: http://doi.wiley.com/10.1111/j.1467-6419.2004.00234.x.

Koundouri, P., 2004b. Potential for groundwater management: Gisser-Sanchez effect reconsidered. Water Resources Research, 40(6).

Koundouri, P., 2000. Three Approaches to Measuring Natural Resource Scarcity: Theory and Application to Groundwater. University of Cambridge. Available at: http://mpra.ub.uni-muenchen.de/38265/.

Lopez, M.C. et al., 2012. Comparing the effectiveness of regulation and pro-social emotions to enhance cooperation: Experimental evidence from fishing communities in Colombia. Economic Inquiry, 50(1), pp.131-142.

Narloch, U., Pascual, U. \& Drucker, A.G., 2012. Collective action dynamics under external rewards: Experimental insights from Andean farming communities. World Development, 40(10), pp.2096-2107. Available at: http://dx.doi.org/10.1016/j.worlddev.2012.03.014.

Ostrom, E., 1990. Governing the commons: The evolution of institutions for collective action, Cambridge: Cambridge University Press.

Peterson, J.M. \& Ding, Y., 2005. Economic adjustments to groundwater depletion in the high plains: Do water-saving irrigation systems save water? American Journal of Agricultural Economics, 87(1), pp.147-159.

Pfeiffer, L. \& Lin, C.-Y.C., 2014. Does efficient irrigation technology lead to reduced groundwater extraction? Empirical evidence. Journal of Environmental Economics and Management, 67(2), pp.189-208.

Pfeiffer, L. \& Lin, C.-Y.C., 2012. Groundwater pumping and spatial externalities in agriculture. Journal of Environmental Economics and Management, 64(1), pp.1630.

Pigou, A.C., 1920. The economics of welfare, London: Macmillan and Co.

Richey, A.S. et al., 2015. Uncertainty in global groundwater storage estimates in a total groundwater stress framework. Water Resources Research, 51(7), pp.5198-5216.

Rode, J., Gómez-Baggethun, E. \& Krause, T., 2014. Motivation crowding by economic incentives in conservation policy: A review of the empirical evidence. Ecological Economics, 117, pp.270-282. Available at: http://www.sciencedirect.com/science/article/pii/S0921800914003668.

Rodriguez-Sickert, C., Guzmán, R.A. \& Cárdenas, J.C., 2008. Institutions influence preferences: Evidence from a common pool resource experiment. Journal of Economic Behavior \& Organization, 67(1), pp.215-227. Available at: http://linkinghub.elsevier.com/retrieve/pii/S0167268107001412.

Rosenthal, E., 2008. Motivated by a tax, irish spurn plastic bags. New York Times.

Savage, J. \& Brozović, N., 2011. Spatial externalities and strategic behavior in groundwater pumping. In AERE Summer Conference. Seattle, Washington.

Scheierling, S.M., Loomis, J.B. \& Young, R.A., 2006. Irrigation water demand: A metaanalysis of price elasticities. Water Resources Research, 42(1), pp.1-9. 
Schoengold, K., Sunding, D.L. \& Moreno, G., 2006. Price elasticity reconsidered: Panel estimation of an agricultural water demand function. Water Resources Research, 42(9). Available at: http://doi.wiley.com/10.1029/2005WR004096.

Schuerhoff, M., Weikard, H.-P. \& Zetland, D., 2013. The life and death of the Dutch groundwater tax. Water policy, 15(6), pp.1064-1077.

Smith, S.M. et al., 2018. Responding to a groundwater crisis: The effects of self-imposed economic incentives. Journal of the Association for Environmental and Resource Economists, 5(1).

Taylor, R.G. et al., 2013. Ground water and climate change. Nature Climate Change, 3(4), pp.322-329. Available at: 10.1038/nclimate1744.

Titmuss, R.M., 1971. Gift relationship: From human blood to social policy, New York: Pantheon Books.

U.S. Department of Agriculture, 2012. Agricultural Census, County Data,

Vyrastekova, J. \& Soest, D. van, 2003. Centralized Common-Pool Management and Local Community Participation. Land Economics, 79(4), pp.500-514. Available at: http://le.uwpress.org/content/79/4/500\%5Cnhttp://le.uwpress.org/content/79/4/500.s hort.

Weiler, S. \& Seidl, A., 2004. What's in a name? Extracting econometric drivers to assess the impact of National Park designation. Journal of Regional Science, 44(2), pp.245-262. Available at: http://onlinelibrary.wiley.com/doi/10.1111/j.00224146.2004.00336.x/full.

Worthington, V., Burt, O. \& Brustkern, R., 1985. Optimal management of a confined groundwater system. Journal of Environmental Economics and Management, 12(3), pp.229-245. Available at: http://www.sciencedirect.com/science/article/pii/0095069685900324.

Wunder, S., Engel, S. \& Pagiola, S., 2008. Taking stock: A comparative analysis of payments for environmental services programs in developed and developing countries. Ecological economics, 65, pp.834-852. Available at: http://www.sciencedirect.com/science/article/pii/S0921800908001432.

Yang, H., Zhang, X. \& Zehnder, A.J.B., 2003. Water scarcity, pricing mechanism and institutional reform in northern China irrigated agriculture. Agricultural Water Management, 61(2), pp.143-161. Available at:

http://www.sciencedirect.com/science/article/pii/S0378377402001646.

Zilberman, D., Chakravorty, U. \& Shah, F., 1997. Efficient management of water in agriculture. In D. D. Parker \& Y. Tsur, eds. Decentralization and Coordination of Water Resource Management. New York: Springer, pp. 221-246. 


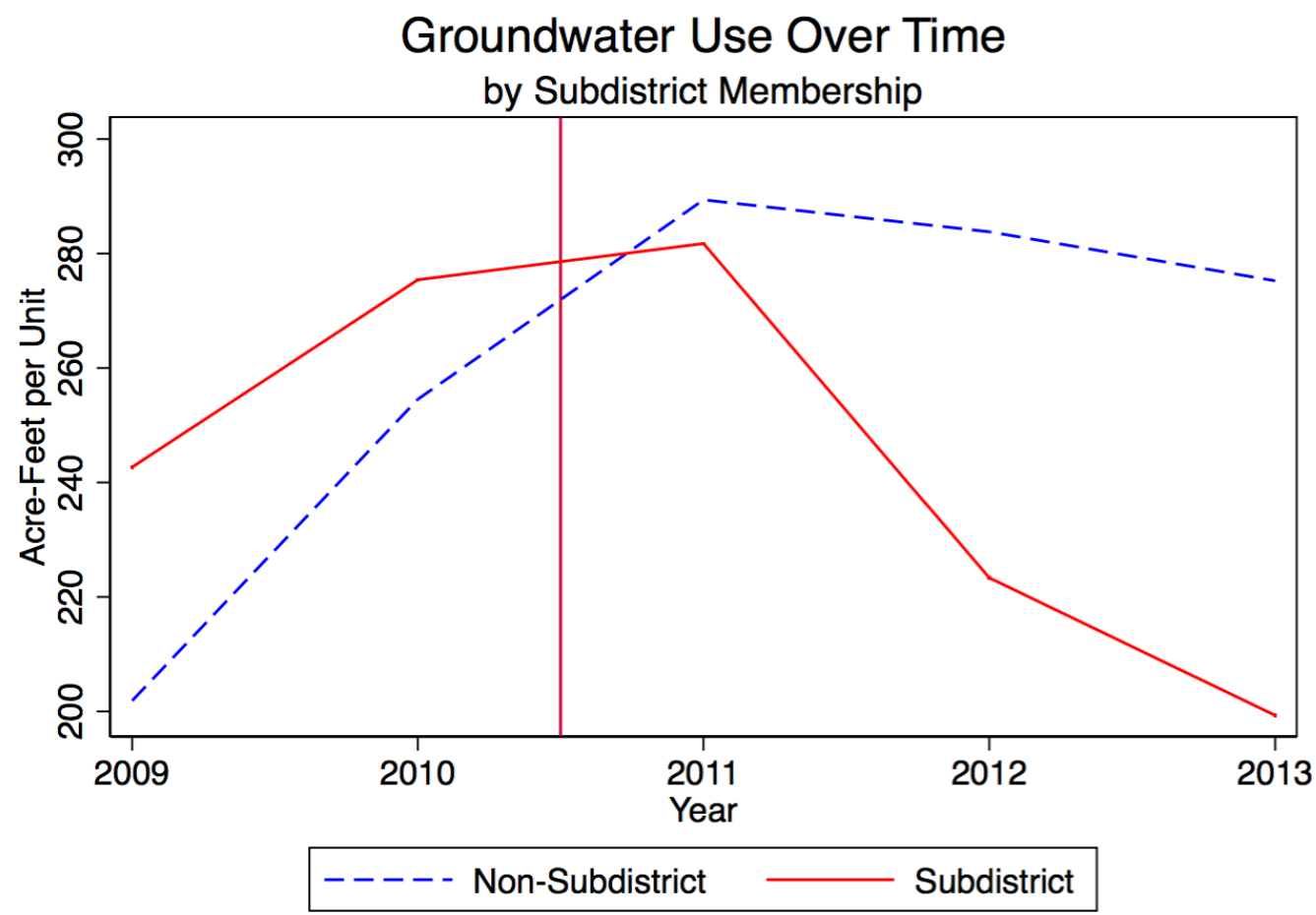

Fig. 1. Average groundwater extraction per unit by year measured in acre-feet. Left of the vertical line (maroon) are observations prior to intervention and to the right are after intervention Source: Smith et al. 2018. 


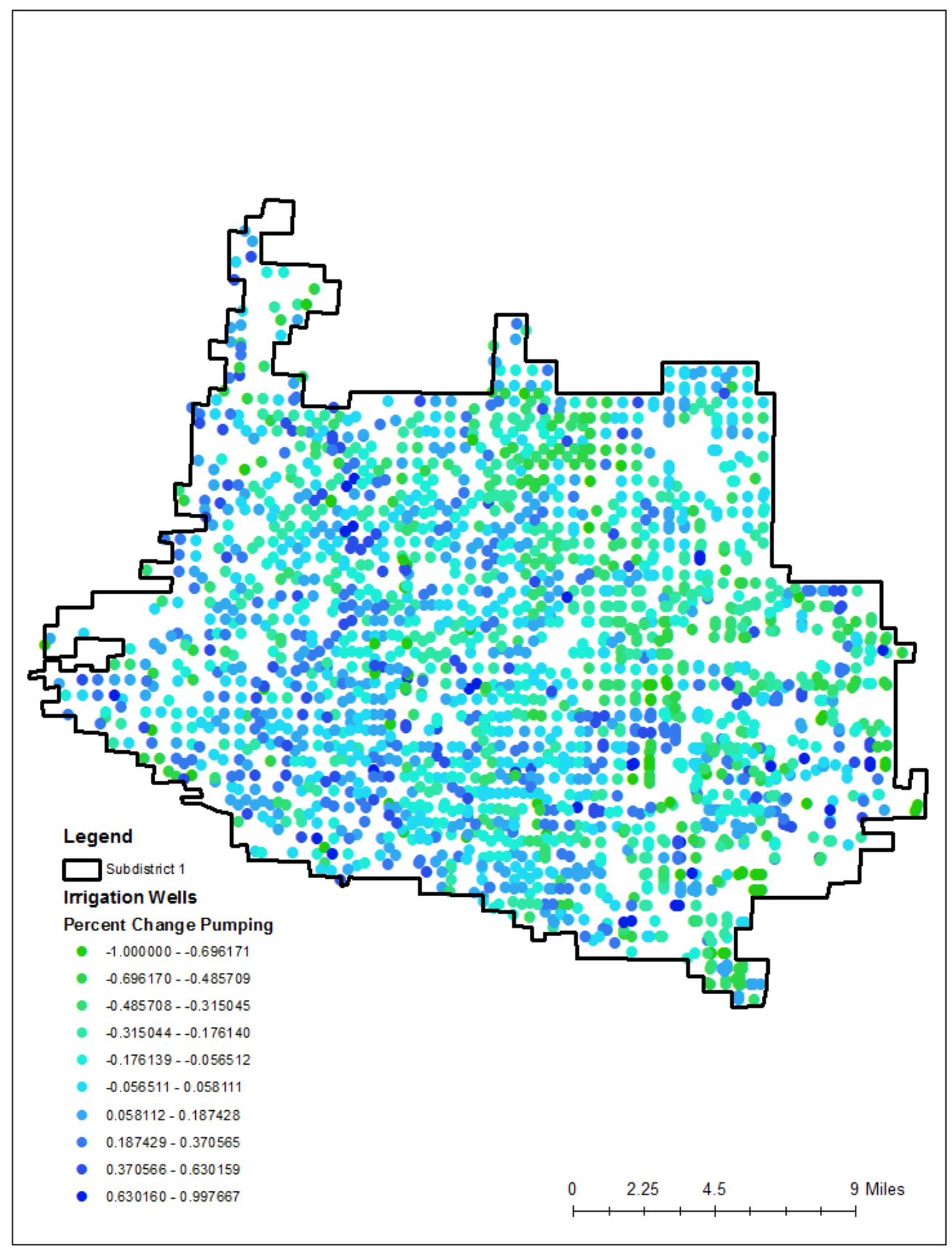

Fig. 2. Variation of change in pumping by well within the subdistrict. Percent change is based on comparing annual average pumping at individual wells preintervention (2009-2010) to post-intervention (2010-2013). The map provides a spatial visualization of the changes 
Table 1: Summary Statistics

\begin{tabular}{|c|c|c|c|}
\hline Variable & Obs & Mean & Std. Dev. \\
\hline Pumping (AF) & 15,239 & 137.22 & 130.08 \\
\hline \multicolumn{4}{|l|}{ Neighbor Pumping } \\
\hline .25 Miles & 15,239 & $1,027.23$ & 750.96 \\
\hline 1 Mile & 15,239 & $4,241.54$ & $2,756.22$ \\
\hline 2 Miles & 15,239 & $8,346.81$ & $5,308.27$ \\
\hline 3 Miles & 15,239 & $12,230.23$ & $7,732.55$ \\
\hline \multicolumn{4}{|l|}{ Own Nearby Pumping } \\
\hline .25 Miles & 15,239 & 54.82 & 98.74 \\
\hline 1 Mile & 15,239 & 71.63 & 162.86 \\
\hline 2 Miles & 15,239 & 77.78 & 204.49 \\
\hline 3 Miles & 15,239 & 80.87 & 240.90 \\
\hline Permit Flow (CFS) & 15,239 & 2.44 & 1.81 \\
\hline Subdistrict 1 & 15,239 & 0.70 & 0.46 \\
\hline Pumping Fee & 15,239 & 27.17 & 33.34 \\
\hline Surface Water & 15,239 & 170.40 & 404.29 \\
\hline Parcels Served & 15,239 & 1.62 & 1.34 \\
\hline Irrigated Acreage ${ }^{\wedge}$ & 15,239 & 80.50 & 63.39 \\
\hline Sprinkler $^{\wedge}$ & 15,239 & 0.85 & 0.33 \\
\hline Well Depth & 15,239 & 212.97 & 308.85 \\
\hline Groundwater Height & 14,794 & $7,608.24$ & 59.88 \\
\hline
\end{tabular}


Table 2: Change in Groundwater Height

\begin{tabular}{lcccc}
\hline \multirow{2}{*}{ VARIABLES } & $(1)$ & $(2)$ & $(3)$ & $(4)$ \\
& GW Depth & GW Depth & GW Depth & GW Depth \\
Own Pumping & & & & \\
& $-0.00361^{* * *}$ & $-0.00357^{* * *}$ & $-0.00361^{* * *}$ & $-0.00368^{* * *}$ \\
Neighbor Pumping & $(0.000604)$ & $(0.000600)$ & $(0.000601)$ & $(0.000602)$ \\
& $-0.000551^{* * *}$ & $-0.000194^{* * *}$ & $-0.000108^{* * *}$ & $-7.74 \mathrm{e}-05^{* * *}$ \\
Own Nearby Pumping & $(5.30 \mathrm{e}-05)$ & $(1.33 \mathrm{e}-05)$ & $(6.63 \mathrm{e}-06)$ & $(4.50 \mathrm{e}-06)$ \\
& $-0.00128^{* *}$ & -0.000359 & $-7.84 \mathrm{e}-05$ & $-1.14 \mathrm{e}-05$ \\
Constant & $(0.000576)$ & $(0.000377)$ & $(0.000246)$ & $(0.000179)$ \\
& $6.966^{* * *}$ & $7.166^{* * *}$ & $7.221^{* * *}$ & $7.255^{* * *}$ \\
& $(0.372)$ & $(0.375)$ & $(0.373)$ & $(0.375)$ \\
Range & & & & \\
Observations & $0.25 \mathrm{Miles}$ & $1 \mathrm{Mile}$ & $2 \mathrm{Miles}$ & $3 \mathrm{Miles}$ \\
R-squared & 14,674 & 14,674 & 14,674 & 14,674 \\
\hline
\end{tabular}

Note: Dependent variable is change in groundwater height from year t -1 to $t$ at well $i$ in year $t$. Well pumping is AF pumped at well $i$ in year t. Neighbor pumping and own pumping are cumulative pumping within the specified range. Year fixed effects are suppressed. Robust standard errors, clustered by well, are in parentheses $* * * \mathrm{p}<0.01, * * \mathrm{p}<0.05,{ }^{*} \mathrm{p}<0.1$ 
Table 3: Overall Well Level Change

\begin{tabular}{|c|c|c|c|}
\hline VARIABLES & $\begin{array}{c}(1) \\
\text { Acre Feet }\end{array}$ & $\begin{array}{c}(2) \\
\text { Acre Feet }\end{array}$ & $\begin{array}{c}(3) \\
\text { Acre Feet }(\log ) \\
\end{array}$ \\
\hline Subdistrict & $\begin{array}{c}8.624 \\
(8.059)\end{array}$ & $\begin{array}{c}6.203 \\
(8.063)\end{array}$ & $\begin{array}{l}0.250 * * \\
(0.0987)\end{array}$ \\
\hline Subdistrict x Post & $\begin{array}{c}-66.49 * * * \\
(4.694)\end{array}$ & & \\
\hline Fee & & $\begin{array}{c}-0.952 * * * \\
(0.0679)\end{array}$ & \\
\hline $\ln (\mathrm{Fee}+40)$ & & & $\begin{array}{c}-0.709 * * * \\
(0.0550)\end{array}$ \\
\hline Surface Water & $\begin{array}{c}-0.0354 * * \\
(0.0141)\end{array}$ & $\begin{array}{c}-0.0355^{* *} \\
(0.0141)\end{array}$ & $\begin{array}{r}-0.000164 \\
(0.000127)\end{array}$ \\
\hline Surface Water x Decree & $\begin{array}{l}0.00834 \\
(0.0195)\end{array}$ & $\begin{array}{l}0.00945 \\
(0.0194)\end{array}$ & $\begin{array}{c}-0.000198 \\
(0.000201)\end{array}$ \\
\hline Surface Water x Decree x Post & $\begin{array}{c}-0.000857 \\
(0.0153)\end{array}$ & $\begin{array}{l}-0.0158 \\
(0.0152)\end{array}$ & $\begin{array}{c}0.000233 \\
(0.000173)\end{array}$ \\
\hline Parcels Served & $\begin{array}{c}5.863 * * \\
(2.678)\end{array}$ & $\begin{array}{l}5.986 * * \\
(2.678)\end{array}$ & $\begin{array}{c}0.128 * * * \\
(0.0264)\end{array}$ \\
\hline Irrigated Acreage & $\begin{array}{c}0.944 * * * \\
(0.0693)\end{array}$ & $\begin{array}{c}0.942 * * * \\
(0.0693)\end{array}$ & $\begin{array}{c}0.00661 * * * \\
(0.000625)\end{array}$ \\
\hline Sprinkler Indicator & $\begin{array}{c}13.73 * * \\
(6.872)\end{array}$ & $\begin{array}{c}13.76^{* *} \\
(6.860)\end{array}$ & $\begin{array}{c}1.719 * * * \\
(0.101)\end{array}$ \\
\hline Latitude & $\begin{array}{c}-0.00119 * * * \\
(0.000259)\end{array}$ & $\begin{array}{c}-0.00118 * * * \\
(0.000259)\end{array}$ & $\begin{array}{c}-1.12 \mathrm{e}-05 * * * \\
(3.50 \mathrm{e}-06)\end{array}$ \\
\hline Longitude & $\begin{array}{c}0.000174 \\
(0.000156)\end{array}$ & $\begin{array}{c}0.000177 \\
(0.000156)\end{array}$ & $\begin{array}{c}3.77 \mathrm{e}-06 * * \\
(1.64 \mathrm{e}-06)\end{array}$ \\
\hline Well Depth & $\begin{array}{c}0.115 * * * \\
(0.0112)\end{array}$ & $\begin{array}{c}0.115 * * * \\
(0.0112)\end{array}$ & $\begin{array}{c}0.00108 * * * \\
(8.89 \mathrm{e}-05)\end{array}$ \\
\hline Decreed Flow & $\begin{array}{c}1.290 \\
(0.952)\end{array}$ & $\begin{array}{c}1.296 \\
(0.952)\end{array}$ & $\begin{array}{c}-0.0343 * * * \\
(0.0122)\end{array}$ \\
\hline Constant & $\begin{array}{l}-232.3 \\
(668.9)\end{array}$ & $\begin{array}{l}-244.2 \\
(669.1)\end{array}$ & $\begin{array}{c}-6.703 \\
(7.402)\end{array}$ \\
\hline $\begin{array}{l}\text { Observations } \\
\text { R-squared }\end{array}$ & $\begin{array}{c}15,239 \\
0.483\end{array}$ & $\begin{array}{c}15,239 \\
0.483\end{array}$ & $\begin{array}{c}15,239 \\
0.364\end{array}$ \\
\hline
\end{tabular}

Note: Difference in Difference estimates using acre feet pumped as the dependent variable. Additional controls include year fixed effects and surface ditch fixed effects. Robust standard errors, clustered by well, in parentheses

$* * * \mathrm{p}<0.01, * * \mathrm{p}<0.05, * \mathrm{p}<0.1$ 
Table 4: Spatial Correlation of Changes

\begin{tabular}{lcccc}
\hline & $\begin{array}{c}(1) \\
\text { Acre Feet } \\
\text { VARIABLES }\end{array}$ & $\begin{array}{c}(2) \\
\text { Acre Feet } \\
\text { (Average Change) }\end{array}$ & $\begin{array}{c}(3) \\
\text { Acre Feet }\end{array}$ & $\begin{array}{c}(4) \\
\text { Acre Feet } \\
\text { Average Change) }\end{array}$ \\
\hline $\begin{array}{l}\text { Neighbor Pumping } \\
\text { (Average Change) }\end{array}$ & $0.0219^{* * *}$ & $0.00809^{* * *}$ & $0.00397^{* * *}$ & $0.00322^{* * *}$ \\
& $(0.00530)$ & $(0.00211)$ & $(0.00136)$ & $(0.00108)$ \\
Constant & $1,602^{* *}$ & $1,346^{* *}$ & $1,449^{* *}$ & $1,473^{* *}$ \\
& $(621.8)$ & $(638.8)$ & $(654.6)$ & $(650.6)$ \\
Range & & & & \\
Observations & 0.25 Miles & 1 Mile & 2 Miles & 3 Miles \\
R-squared & 2,123 & 2,123 & 2,123 & 2,123 \\
\hline
\end{tabular}

Cross-Sectional regressions with average pumping post treatment minus average pumping pretreatment as the dependent variable.. Neighbor Pumping is defined similarly but by summing pumping by all wells within the range before averaging across time. Additional but unreported controls are welldepth, decreed flow, and latitude and longitude. Only subdistrict \#1 wells are included. Robust standard errors in parentheses

$* * * \mathrm{p}<0.01, * * \mathrm{p}<0.05, * \mathrm{p}<0.1$

Table 5: Spatial Relationship (OLS)

\begin{tabular}{lcccc}
\hline & $(1)$ & $(2)$ & $(3)$ & $(4)$ \\
VARIABLES & Acre Feet & Acre Feet & Acre Feet & Acre Feet \\
\hline \multirow{2}{*}{ Neighbor Pumping } & $0.00696^{* * * *}$ & $0.00198^{* * * *}$ & $0.000970^{* * * *}$ & $0.000656^{* * *}$ \\
& $(0.00218)$ & $(0.000575)$ & $(0.000282)$ & $(0.000191)$ \\
Own Nearby Pumping & 0.0129 & $0.0543^{* *}$ & $0.0490^{* * *}$ & $0.0321^{* *}$ \\
& $(0.0289)$ & $(0.0228)$ & $(0.0179)$ & $(0.0159)$ \\
& & & & \\
Range & 0.25 Miles & 1 Mile & 2 Miles & 3 Miles \\
Observations & 15,239 & 15,239 & 15,239 & 15,239 \\
R-squared & 0.474 & 0.477 & 0.478 & 0.476 \\
\hline
\end{tabular}

Note: Dependent variable is pumping at well $i$ in year $t$. Neighbor pumping is cumulative pumping within the specified range. Additional controls include surface water supply, \# of parcels served, irrigated acreage, technology used, welldepth, decreed flow, latitude and longitude, and surface ditch fixed effects. Robust standard errors, clustered by well, are in parentheses

*** $\mathrm{p}<0.01,{ }^{* *} \mathrm{p}<0.05,{ }^{*} \mathrm{p}<0.1$ 
Table 6: First Stage Example

(1) (2) (3) (4)

\begin{tabular}{lcccc} 
VARIABLES & Neighbor Pumping & Neighbor Pumping & Neighbor Pumping & Neighbor Pumping \\
\hline & & & & \\
Neighbor Permits & $19.74^{* * *}$ & $21.10^{* * *}$ & $21.62^{* * *}$ & $21.81^{* * *}$ \\
& $(0.301)$ & $(0.238)$ & $(0.212)$ & $(0.199)$ \\
Range & & & & \\
Observations & 0.25 Miles & 1 Mile & 2 Miles & 3 Miles \\
R-squared & 15,239 & 15,239 & 15,239 & 15,239 \\
\hline
\end{tabular}

The dependent variable is aggregated pumping by wells within the specified range of well $\mathrm{i}$ in year $\mathrm{t}$. Neighbor permits is similarly defined but aggregating permitted flow. Additional controls are surface water supply, \# of parcels served, irrigated acreage, technology used, welldepth, decreed flow, latitude and longitude, and surface ditch fixed effects. Robust standard errors, clustered by well, in parentheses $* * * \mathrm{p}<0.01, * * \mathrm{p}<0.05, * \mathrm{p}<0.1$ 
Table 7: Permit Dependence

\begin{tabular}{lcccc}
\hline \multirow{2}{*}{ VARIABLES } & $(1)$ & $(2)$ & $(3)$ & $(4)$ \\
Neighbor Permits & Permit & Permit & Permit & Permit \\
\hline & & & & \\
Own Nearby Permits & 0.000930 & $4.33 \mathrm{e}-06$ & $-4.85 \mathrm{e}-05$ & $-4.48 \mathrm{e}-05$ \\
& $(0.00116)$ & $(0.000315)$ & $(0.000163)$ & $(0.000112)$ \\
Constant & $-0.100^{* * *}$ & $-0.0633^{* * *}$ & $-0.0511^{* * *}$ & $-0.0407^{* * *}$ \\
& $(0.0170)$ & $(0.0143)$ & $(0.0132)$ & $(0.0123)$ \\
& $28.26^{* * *}$ & $29.63^{* * *}$ & $29.08^{* * *}$ & $29.42^{* * *}$ \\
Range & $(10.94)$ & $(10.96)$ & $(10.98)$ & $(10.99)$ \\
Observations & & & & \\
R-squared & 0.25 Miles & 1 Mile & 2 Miles & 3 Miles \\
Number of wdid & 15,239 & 15,239 & 15,239 & 15,239 \\
The & 0.339 & 0.336 & 0.335 & 0.334 \\
\hline
\end{tabular}

The dependent variable is the pemitted flow at well $\mathrm{i}$. Neighbor permits is the aggregated total permitted flow of other wells within the specified range. Because permitted flow does not vary over time, coefficients are reported from a between-effects regressions. Additional controls are surface water supply, \# of parcels served, irrigated acreage, technology used, welldepth, latitude and longitude, and surface ditch fixed effects. Standard errors in parentheses

$* * * \mathrm{p}<0.01, * * \mathrm{p}<0.05, * \mathrm{p}<0.1$ 
Table 8: Spatial Relationship (IV)

\begin{tabular}{lcccc}
\hline & $(1)$ & $(2)$ & $(3)$ & $(4)$ \\
VARIABLES & Acre Feet & Acre Feet & Acre Feet & Acre Feet \\
\hline \multirow{3}{*}{ Neighbor Pumping } & -0.00297 & $-0.00102^{*}$ & -0.000430 & -0.000259 \\
& $(0.00247)$ & $(0.000611)$ & $(0.000298)$ & $(0.000199)$ \\
Own Nearby Pumping & -0.0379 & 0.0113 & 0.00769 & -0.000283 \\
& $(0.0315)$ & $(0.0238)$ & $(0.0183)$ & $(0.0143)$ \\
& & & & \\
Range & 0.25 Miles & 1 Mile & 2 Miles & 3 Miles \\
Observations & 15,239 & 15,239 & 15,239 & 15,239 \\
R-squared & 0.470 & 0.472 & 0.472 & 0.471 \\
\hline
\end{tabular}

Note: Dependent variable is pumping at well $\mathrm{i}$ in year $\mathrm{t}$. Neighbor pumping is cumulative pumping within the specified range instrumented with cumulative permitted flow. Additional controls include surface water supply, \# of parcels served, irrigated acreage, technology used, welldepth, decreed flow, latitude and longitude, and surface ditch fixed effects. Robust standard errors, clustered by well, are in parentheses

$* * * p<0.01, * * p<0.05, * p<0.1$ 
Table 9: Impact of Economic Intervention with Spatial Controls (IV)

\begin{tabular}{lcccc}
\hline & $(1)$ & $(2)$ & $(3)$ & $(4)$ \\
VARIABLES & Acre Feet & Acre Feet & Acre Feet & Acre Feet \\
\hline \multirow{2}{*}{ Neighbor Pumping x Post x Subdistrict } & $-0.0155^{*}$ & $-0.00333^{*}$ & $-0.00314 * * *$ & $-0.00241^{* * *}$ \\
& $(0.00817)$ & $(0.00197)$ & $(0.00108)$ & $(0.000813)$ \\
Neighbor Pumping & -0.00985 & -0.00103 & -0.00101 & -0.000538 \\
& $(0.00938)$ & $(0.00260)$ & $(0.00144)$ & $(0.00112)$ \\
Neighbor Pumping x Subdistrict & 0.00835 & 0.000350 & 0.000627 & 0.000278 \\
Neighbor Pumping x Post & $(0.00957)$ & $(0.00262)$ & $(0.00146)$ & $(0.00113)$ \\
& 0.0125 & 0.00235 & $0.00279 * *$ & $0.00221^{* * *}$ \\
Own Nearby Pumping & $(0.00836)$ & $(0.00201)$ & $(0.00110)$ & $(0.000832)$ \\
& -0.0372 & 0.0121 & 0.00826 & -0.000290 \\
Fee & $(0.0315)$ & $(0.0238)$ & $(0.0184)$ & $(0.0143)$ \\
& $-0.830^{* * *}$ & $-0.821 * * *$ & $-0.736 * * *$ & $-0.717 * * *$ \\
Constant & $(0.0940)$ & $(0.0958)$ & $(0.0930)$ & $(0.0951)$ \\
& -363.6 & -193.9 & -173.6 & -226.2 \\
Range & $(666.7)$ & $(661.7)$ & $(658.5)$ & $(661.2)$ \\
Observations & & & & \\
R-squared & $0.25 \mathrm{Miles}$ & $1 \mathrm{Mile}$ & $2 \mathrm{Miles}$ & $3 \mathrm{Miles}$ \\
\hline
\end{tabular}

Note: Dependent variable is pumping at well $\mathrm{i}$ in year t. Neighbor pumping is cumulative pumping within the specified range instrumented by permitted flow. Additional controls include surface water supply, \# of parcels served, irrigated acreage, technology used, welldepth, decreed flow, latitude and longitude, and surface ditch fixed effects. Robust standard errors, clustered by well, are in parentheses

$* * * \mathrm{p}<0.01, * * \mathrm{p}<0.05, * \mathrm{p}<0.1$ 
Table 10: Impact of Economic Intervention with Spatial Controls and Groundwater Height

\begin{tabular}{lcccc}
\hline & $(1)$ & $(2)$ & $(3)$ & $(4)$ \\
VARIABLES & Acre Feet & Acre Feet & Acre Feet & Acre Feet \\
\hline Neighbor Pumping x Post x Subdistrict & $-0.0163^{*}$ & $-0.00355^{*}$ & $-0.00323^{* * *}$ & $-0.00255^{* * *}$ \\
& $(0.00843)$ & $(0.00206)$ & $(0.00111)$ & $(0.000846)$ \\
Neighbor Pumping & -0.0114 & -0.00148 & -0.00126 & -0.000814 \\
& $(0.00954)$ & $(0.00268)$ & $(0.00147)$ & $(0.00117)$ \\
Neighbor Pumping x Subdistrict & 0.0106 & 0.000923 & 0.00103 & 0.000697 \\
& $(0.00975)$ & $(0.00272)$ & $(0.00150)$ & $(0.00118)$ \\
Neighbor Pumping x Post & 0.0130 & 0.00250 & $0.00281 * *$ & $0.00228^{* * *}$ \\
& $(0.00863)$ & $(0.00211)$ & $(0.00114)$ & $(0.000865)$ \\
Own Nearby Pumping & -0.0306 & 0.0168 & 0.0116 & 0.00216 \\
& $(0.0301)$ & $(0.0221)$ & $(0.0173)$ & $(0.0135)$ \\
Fee & $-0.840^{* * *}$ & $-0.832 * * *$ & $-0.741 * * *$ & $-0.712^{* * *}$ \\
GW Height & $(0.0975)$ & $(0.100)$ & $(0.0970)$ & $(0.0988)$ \\
Constant & $0.103 *$ & $0.110^{*}$ & $0.113 *$ & $0.116^{*}$ \\
& $(0.0613)$ & $(0.0616)$ & $(0.0621)$ & $(0.0628)$ \\
& $-1,247$ & $-1,164$ & $-1,185$ & $-1,277$ \\
Range & $(1,007)$ & $(1,002)$ & $(1,005)$ & $(1,019)$ \\
Observations & & & & \\
R-squared & $0.25 \mathrm{Miles}$ & $1 \mathrm{Mile}$ & $2 \mathrm{Miles}$ & 14,779 \\
\hline
\end{tabular}

Note: Dependent variable is pumping at well $i$ in year t. Neighbor pumping is cumulative pumping within the specified range instrumented by permitted flow. Additional controls include surface water supply, \# of parcels served, irrigated acreage, technology used, welldepth, decreed flow, latitude and longitude, and surface ditch fixed effects. Robust standard errors, clustered by well, are in parentheses

$* * * \mathrm{p}<0.01, * * \mathrm{p}<0.05, * \mathrm{p}<0.1$ 


\section{APPENDIX}

Table A1: Equal Trends

\begin{tabular}{lcccc}
\hline & $(1)$ & $(2)$ & $(3)$ & $(4)$ \\
VARIABLES & Acre Feet & Acre Feet & Acre Feet & Acre Feet \\
\hline \multirow{2}{*}{ Neighbor Pumping } & -0.00580 & 0.000465 & -0.000221 & $9.62 \mathrm{e}-05$ \\
Neighbor Pumping x Subdistrict & $(0.0103)$ & $(0.00294)$ & $(0.00167)$ & $(0.00132)$ \\
& 0.00136 & -0.00194 & -0.000567 & -0.000624 \\
Neighbor Pumping x 2010 & $(0.0105)$ & $(0.00296)$ & $(0.00168)$ & $(0.00133)$ \\
& -0.00603 & 0.00202 & 0.00131 & 0.00119 \\
Neighbor Pumping x Subdistrict x 2010 & $(0.00868)$ & $(0.00249)$ & $(0.00139)$ & $(0.00109)$ \\
& 0.00572 & -0.00244 & -0.00161 & -0.00140 \\
Own Nearby Pumping & $(0.00906)$ & $(0.00253)$ & $(0.00142)$ & $(0.00110)$ \\
& $-0.0701 *$ & -0.0131 & -0.00259 & -0.00883 \\
Constant & $(0.0361)$ & $(0.0268)$ & $(0.0209)$ & $(0.0165)$ \\
& 230.4 & 441.3 & 465.9 & 427.0 \\
Range & $(749.0)$ & $(734.8)$ & $(730.7)$ & $(732.0)$ \\
Observations & & & & \\
R-squared & $0.25 \mathrm{Miles}$ & $1 \mathrm{Mile}$ & $2 \mathrm{Miles}$ & 3 Miles \\
\hline
\end{tabular}

Note: Dependent variable is pumping at well $\mathrm{i}$ in year t. Neighbor pumping is cumulative pumping within the specified range instrumented by permitted flow. Additional controls include surface water supply, \# of parcels served, irrigated acreage, technology used, welldepth, decreed flow, latitude and longitude, and surface ditch fixed effects. Robust standard errors, clustered by well, are in parentheses $* * * \mathrm{p}<0.01,{ }^{* *} \mathrm{p}<0.05,{ }^{*} \mathrm{p}<0.1$ 
Table A2: Impact of Economic Intervention with Spatial Controls (OLS)

\begin{tabular}{lcccc}
\hline & $(1)$ & $(2)$ & $(3)$ & $(4)$ \\
VARIABLES & Acre Feet & Acre Feet & Acre Feet & Acre Feet \\
\hline \multirow{2}{*}{ Neighbor Pumping x Post x Subdistrict } & $-0.0102^{*}$ & -0.000584 & -0.000909 & -0.000525 \\
& $(0.00596)$ & $(0.00155)$ & $(0.000807)$ & $(0.000619)$ \\
Neighbor Pumping & 0.00460 & $0.00491 * *$ & $0.00276^{* *}$ & $0.00260^{* * *}$ \\
Neighbor Pumping x Subdistrict & $(0.00713)$ & $(0.00202)$ & $(0.00108)$ & $(0.000854)$ \\
& 0.00130 & $-0.00384^{*}$ & $-0.00249^{* *}$ & $-0.00245^{* * *}$ \\
Neighbor Pumping x Post & $(0.00736)$ & $(0.00206)$ & $(0.00110)$ & $(0.000866)$ \\
& 0.00613 & -0.000438 & 0.000583 & 0.000316 \\
Own Nearby Pumping & $(0.00600)$ & $(0.00156)$ & $(0.000816)$ & $(0.000630)$ \\
Fee & 0.00916 & $0.0539 * *$ & $0.0498^{* * *}$ & $0.0326^{* *}$ \\
& $(0.0283)$ & $(0.0226)$ & $(0.0178)$ & $(0.0157)$ \\
Constant & $-0.810^{* * *}$ & $-0.843 * * *$ & $-0.818^{* * *}$ & $-0.826^{* * *}$ \\
& $(0.0831)$ & $(0.0896)$ & $(0.0884)$ & $(0.0900)$ \\
Range & -70.42 & 129.8 & 201.4 & 90.33 \\
Observations & $(659.5)$ & $(646.3)$ & $(640.0)$ & $(646.9)$ \\
R-squared & & & & \\
\hline Ne: Diles & $0.25 \mathrm{Miles}$ & $1 \mathrm{Mile}$ & $2 \mathrm{Miles}$ & $3 \mathrm{Miles}$ \\
& 15,239 & 15,239 & 15,239 & 15,239 \\
& 0.484 & 0.487 & 0.489 & 0.488 \\
\hline
\end{tabular}

Note: Dependent variable is pumping at well $i$ in year t. Neighbor pumping is cumulative pumping within the specified range. Additional controls include surface water supply, \# of parcels served, irrigated acreage, technology used, welldepth, decreed flow, latitude and longitude, and surface ditch fixed effects. Robust standard errors, clustered by well, are in parentheses

$* * * \mathrm{p}<0.01, * * \mathrm{p}<0.05, * \mathrm{p}<0.1$ 


\section{Robustness Checks}

A concern is that pumping behavior may not have changed within the subdistrict so much as pumping behavior changed outside the subdistrict. Even though I have shown there was not distinctive change from 2009 to 2010, this does not preclude behavior diverging afterwards for reasons other than the intervention. In fact, looking at the main results in Table 10 there is some evidence that irrigators outside the subdistrict slightly increased their pumping in response to nearby pumping post-intervention. On the one hand, this could be driven by irrigators outside the subdistrict responding in a non-cooperative in attempt to capture more water before they too are faced with pumping fees. On the other hand, increased non-cooperative behavior may be attributable to observing lower aquifer levels, which is expected to exacerbate common-pool issues due to increased scarcity. If the latter is the root cause of the increase, I can be more confident that our estimates are causal and those inside the subdistrict would have made similar increases in noncooperative behavior absent intervention. Regardless, I re-estimate equation (7) but using only subdistrict wells and assess the single difference. Reported in Table A3, the coefficients on nearby pumping post intervention remain negative but smaller in magnitude and not as statistically significant, albeit smaller in magnitude.

Recognizing wells that are closer are more observable and have a larger impact on the underlying groundwater at a given well, I adjust the pumping and permit by weights.

Similar to Pfeiffer \& Lin (2012), I weight each well in the summation by $\frac{a b s\left(H_{i t}-H_{j t}\right)}{d_{i j}}$, 
where $a b s\left(H_{i t}-H_{j t}\right)$ is the absolute value of the difference in groundwater height beneath well $i$ and $j$ in year $t$, and $d_{i j}$ is the distance between them. Weighting the sums and re-estimating equation (7) yields the coefficients shown in Table A4. Qualitatively, the results are stable. Weighted pumping within a quarter mile is on average 20,067.27 (units are: feet ${ }^{2} /($ Acres $\times$ Miles)), resulting in a total change on average of $12.3 \mathrm{AF}$. Noticeably, the coefficient estimate is consistent across all ranges. This, however, is because the additional range is heavily discounted. That is, when expanding to the 2 mile radius, the average weighted pumping summation increases only to 21,458.66.

Last, rather than using attributes of well $i$ and instrumenting for total nearby pumping with total nearby permits, I could utilize individual regressions which predict pumping at well $j$ in year $t$. Specifically, I could estimate equation (A1) below:

$W_{j t}=\alpha_{1}+\alpha_{2} \times$ fee $_{j t}+\alpha_{3} \times$ Subdistrict $_{j t}+\delta^{\prime} \boldsymbol{\omega}_{j t}+\tau_{t}+\delta_{d}+\varepsilon_{i j}$

Here $\boldsymbol{\omega}_{j t}$ contains covariates as defined above, and most notably permitted flow at well $j$. Then, using these predicted values, I sum up nearby pumping and then estimate equation (7) from the main text. Results are in Table A5 and qualitatively similar though slightly smaller in magnitude. 
Table A3: Impact of Economic Intervention with Spatial Controls (IV-Single Difference)

\begin{tabular}{lcccc}
\hline & $(1)$ & $(2)$ & $(3)$ & $(4)$ \\
VARIABLES & Acre Feet & Acre Feet & Acre Feet & Acre Feet \\
\hline \multirow{2}{*}{ Neighbor Pumping x Post } & -0.00160 & $-0.000672^{*}$ & -0.000277 & -0.000172 \\
& $(0.00160)$ & $(0.000389)$ & $(0.000196)$ & $(0.000133)$ \\
Neighbor Pumping & $-0.00495^{*}$ & $-0.00159^{* *}$ & $-0.000862^{* * *}$ & $-0.000553^{* *}$ \\
& $(0.00274)$ & $(0.000648)$ & $(0.000330)$ & $(0.000220)$ \\
Own Nearby Pumping & -0.0162 & 0.0163 & 0.0245 & 0.0138 \\
Fee & $(0.0343)$ & $(0.0243)$ & $(0.0227)$ & $(0.0191)$ \\
& $-0.116^{* * *}$ & $-0.105^{* * *}$ & $-0.115^{* * *}$ & $-0.114^{* * *}$ \\
Constant & $(0.0389)$ & $(0.0406)$ & $(0.0402)$ & $(0.0399)$ \\
& $-1,552^{*}$ & $-1,421$ & $-1,277$ & $-1,406$ \\
Range & $(903.7)$ & $(922.4)$ & $(890.4)$ & $(878.9)$ \\
Observations & & & & \\
R-squared & 0.25 Miles & 1 Mile & 2 Miles & 3 Miles \\
\hline
\end{tabular}

Note: Dependent variable is pumping at well $\mathrm{i}$ in year t. Only subdistrict \#1 wells are included. Neighbor pumping is cumulative pumping within the specified range instrumented by permitted flow. Additional controls include surface water supply, \# of parcels served, irrigated acreage, technology used, welldepth, decreed flow, latitude and longitude, and surface ditch fixed effects. Robust standard errors, clustered by well, are in parentheses

$* * * \mathrm{p}<0.01, * * \mathrm{p}<0.05, * \mathrm{p}<0.1$ 
Table A4: Impact of Economic Intervention with Spatial Controls (IV and Weights)

(1)

VARIABLES

Neighbor Pumping x Post x Subdistrict

Neighbor Pumping

Neighbor Pumping x Subdistrict

Neighbor Pumping x Post

Own Nearby Pumping

Fee

Constant

Range

Observations

R-squared
(2)

(3)

Acre Feet Acre Feet Acre Feet Acre Feet

\begin{tabular}{cccc}
$-0.000607 *$ & $-0.000612^{*}$ & $-0.000623^{*}$ & $-0.000628^{*}$ \\
$(0.000355)$ & $(0.000350)$ & $(0.000348)$ & $(0.000346)$ \\
$-3.73 \mathrm{e}-05$ & $-4.12 \mathrm{e}-05$ & $-4.40 \mathrm{e}-05$ & $-4.65 \mathrm{e}-05$ \\
$(0.000216)$ & $(0.000212)$ & $(0.000210)$ & $(0.000209)$ \\
$3.35 \mathrm{e}-05$ & $3.70 \mathrm{e}-05$ & $3.97 \mathrm{e}-05$ & $4.23 \mathrm{e}-05$ \\
$(0.000217)$ & $(0.000213)$ & $(0.000211)$ & $(0.000209)$ \\
$0.000595^{*}$ & $0.000600^{*}$ & $0.000612^{*}$ & $0.000616^{*}$ \\
$(0.000356)$ & $(0.000350)$ & $(0.000348)$ & $(0.000347)$ \\
$0.00498^{* *}$ & $0.00521^{* *}$ & $0.00522^{* *}$ & $0.00519^{* *}$ \\
$(0.00217)$ & $(0.00214)$ & $(0.00214)$ & $(0.00215)$ \\
$-0.898^{* * *}$ & $-0.894 * * *$ & $-0.890^{* * *}$ & $-0.889 * * *$ \\
$(0.0692)$ & $(0.0697)$ & $(0.0699)$ & $(0.0701)$ \\
-233.5 & -239.7 & -239.9 & -240.4 \\
$(669.4)$ & $(669.4)$ & $(669.4)$ & $(669.4)$ \\
& & & \\
0.25 Miles & $1 \mathrm{Mile}$ & $2 \mathrm{Miles}$ & $3 \mathrm{Miles}$ \\
15,239 & 15,239 & 15,239 & 15,239 \\
0.485 & 0.486 & 0.486 & 0.486 \\
\hline
\end{tabular}

Note: Dependent variable is pumping at well $\mathrm{i}$ in year t. Only subdistrict \#1 wells are included. Neighbor pumping is cumulative pumping within the specified range instrumented by permitted flow with both being weighted by distance and difference in groundwater height prior to the summation. Additional controls include surface water supply, \# of parcels served, irrigated acreage, technology used, welldepth, decreed flow, latitude and longitude, and surface ditch fixed effects. Robust standard errors, clustered by well, are in parentheses $* * * \mathrm{p}<0.01, * * \mathrm{p}<0.05, * \mathrm{p}<0.1$ 
Table A5: Manual First Stage

\begin{tabular}{lcccc}
\hline & $(1)$ & $(2)$ & $(3)$ & $(4)$ \\
VARIABLES & Acre Feet & Acre Feet & Acre Feet & Acre Feet \\
\hline Neighbor Pumping x Post x Subdistrict & -0.0104 & -0.00164 & $-0.00225^{* *}$ & $-0.00174^{* *}$ \\
& $(0.00755)$ & $(0.00195)$ & $(0.00109)$ & $(0.000799)$ \\
Neighbor Pumping & -0.00155 & 0.00158 & 0.000587 & 0.000797 \\
& $(0.00923)$ & $(0.00258)$ & $(0.00150)$ & $(0.00114)$ \\
Neighbor Pumping x Subdistrict & 0.00258 & -0.00221 & -0.00103 & -0.00114 \\
& $(0.00932)$ & $(0.00257)$ & $(0.00150)$ & $(0.00114)$ \\
Neighbor Pumping x Post & 0.00817 & 0.000943 & $0.00209^{*}$ & $0.00167^{* *}$ \\
& $(0.00765)$ & $(0.00198)$ & $(0.00110)$ & $(0.000813)$ \\
Own Nearby Pumping & -0.0395 & 0.0521 & $0.0612^{*}$ & 0.0579 \\
& $(0.0381)$ & $(0.0426)$ & $(0.0361)$ & $(0.0361)$ \\
Fee & $-0.867 * * *$ & $-0.861 * * *$ & $-0.796^{* * *}$ & $-0.786^{* * *}$ \\
Constant & $(0.0862)$ & $(0.0918)$ & $(0.0900)$ & $(0.0909)$ \\
& -290.3 & -23.15 & 120.0 & 112.4 \\
Range & $(660.9)$ & $(648.3)$ & $(641.5)$ & $(641.9)$ \\
Observations & & & & \\
R-squared & 0.25 Miles & 1 Mile & 2 Miles & 3 Miles \\
\hline
\end{tabular}

Note: Dependent variable is pumping at well i in year t. Only subdistrict \#1 wells are included. Neighbor pumping is cumulative pumping within the specified range instrumented by permitted flow. Additional controls include surface water supply, \# of parcels served, irrigated acreage, technology used, welldepth, decreed flow, latitude and longitude, and surface ditch fixed effects. Robust standard errors, clustered by well, are in parentheses

$* * * \mathrm{p}<0.01, * * \mathrm{p}<0.05, * \mathrm{p}<0.1$ 